\section{ECONOMICS}

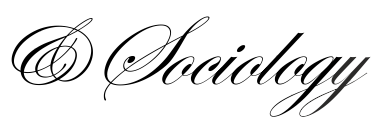

Voropai, O., Pichyk, K., \& Chala, N. (2019). Increasing competitiveness of higher education in Ukraine through value co-creation strategy. Economics and Sociology, 12(4), 228-240. doi:10.14254/2071-789X.2019/12-4/14

\title{
INCREASING COMPETITIVENESS OF HIGHER EDUCATION IN UKRAINE THROUGH VALUE CO- CREATION STRATEGY
}

\author{
Olga Voropai, \\ National University "Kyiv-Mohyla \\ Academy", \\ Kyiv, Ukraine \\ E-mail: \\ olga.voropai@ukma.edu.ua \\ Kateryna Pichyk, \\ National University "Kyiv-Mohyla \\ Academy", \\ Kyiv, Ukraine \\ E-mail:pichykkv@ukma.edu.ua \\ Nina Chala,
National University "Kyiv-Mohyla
Academy",
Kyiv, Ukraine
E-mail:n.chala@ukma.edu.ua
}

Received: February, 2019

1st Revision: April, 2019

Accepted: November, 2019

DOI: $10.14254 / 2071-$

789X.2019/12-4/14

JEL Classification: M25, I31

\begin{abstract}
The value co-creation concept has become a marketing answer to today's challenges, the economy is facing. The field of higher education (HE) is experiencing the same pressure of outer factors as any other service industry. As a result, service providers (colleges and universities), as well as customers (students, graduates and employers) are dissatisfied with the quality of services and the level of generated value. The aim of this paper is to discuss how universities can use value co-creation concept to improve the situation. We consider social media to become engagement platforms for enabling value cocreation. Therefore, this paper discusses their current usage and perspectives for Ukrainian $\mathrm{HE}$ in creating mutual value. Top-five Ukrainian universities in the Webometrics rating are analyzed in terms of their SM activities on Facebook, YouTube and Instagram. The value itself is considered a multi-dimensional category and the co-creation directions are analyzed in terms of the theory of consumption values (TCV) and from the perspective of two customer groups - students and employers. Recommendations include practical tools on engaging students and employers to the VCC process, grouped by the type of the value obtained.
\end{abstract}

Keywords: value co-creation, TCV, social media marketing, higher education, Ukraine.

\section{Introduction}

During the last couple of decades both employers and graduates in the post-Soviet countries have been the hostages of an old education system, where knowledge and skills, provided by higher education (HE) establishments were no longer valued by the labor market. Therefore, it is now crucial for universities to integrate employers and students into the education process and value creation. Successful implementation of the value co-creation (VCC) principles and an active actor-to-actor (A2A) collaboration needs the use of platforms to enable communication among all the participants. Social media platforms have all the 
necessary attributes to become efficient tools for value co-creation. Higher generated value will result in stronger competitive advantages of educational institutions. The objectives of this paper are as follows:

- to distinguish the role of social media in implementing VCC strategy by HE institutions;

- to analyze how social media platforms are currently used by Ukrainian universities in terms of value co-creation;

- to outline the types of perceived value, which can be generated through value proposition for three main groups of stakeholders: universities, students, and employers.

The significance of this paper is, on the one hand, in incorporating employers into the process of VCC as active actors. On the other hand, the aim is to show how current situation with education value proposition in Ukraine can be improved by using social media platforms and what benefits will actors gain.

Though the concept of VCC has now widely been discussed across markets and its role in creating competitive advantage is recognized, there is still weak understanding of how it can be applied by HE institutions outside the process of on-campus teaching. Ukrainian universities are not an exception in this regard and thus need a guide on how to use social media tools to implement VCC into their market strategy.

\section{Literature review}

Value is generated on every step of company's activities and hundreds of small interactions contribute to the whole customer perception and satisfaction. Modern marketing science and practice are regarding buying and consumption process as a customer journey (Maechler at al., 2016). Customer experience at each touch point influences the quality of the overall experience, the level of satisfaction and customer loyalty. In higher education market the main service is still created on campus, where students deal with professors. Therefore, most of recent research studies on value co-creation in education examine the methodical aspects of teaching which imply a wider role of students in creating educational content, generating knowledge and designing courses. Chemi and Krogh (2017) present a systematic view on the tools of in class co-production in HE, including Project based learning (PBL), learner-led teaching, collaborative dynamics and others. Bowden and D'Alessandro (2011) analyze how interactive classroom technologies may engage students in co-production and enhance their experience. But concentrating on just one dimension of value co-creation integrating customers to the new product development (NPD) process - these research studies pay no attention to post-production. However, according to the concept of service-dominant (SD) logic, described by Vargo and Lusch (2004), value co-creation covers two sub-processes. The first one implies co-production, where value is created in collaboration with consumers. In terms of HE it mostly includes activities, related to course teaching, either on campus or remotely. The second process, called value-in-use, implies generating value beyond production. The six directions of value co-creation matrix, distinguished by Voropai (2016) in terms of value type and university role partially closed this gap, covering managerial role of students and their marketing activities, beneficial for both parties. And the first contribution of this paper is to broaden the value co-creation in HE beyond production, covering the aspects of communication and post-production experience.

All recent attempts to describe value co-creation in $\mathrm{HE}$ mostly concentrate on $\mathrm{HE}$ institutions and students collaboration, leaving employers behind. Wherein the latter actually form another target segment of university education. Therefore, the second contribution of this paper is to include employers and their resources into the value co-creation process. 
As the concept of value co-creation has only recently been applied in HE, scientific and practical literature lacks conceptual models as well as managerial guidelines on how the process of co-creation should be integrated into overall management system and the mutual benefits that will be generated. An indicative model of value co-creation in higher education, covering co-production and value-in-use, proposed by Dollinger, Lodge and Coates (2018, p. 224) suggests that "these anticipated benefits are for students, quality interactions, satisfaction, and graduate capabilities, and for institutions, student loyalty, university image, and studentuniversity identification". Our objective is to link rather theoretical concept of value co-creation to its practical application through using social media and to different dimension of consumption value, that might be generated.

Considering all mentioned above and broadening the definition, proposed by Voropai (2016), we will regard value co-creation in HE as a holistic process of collaboration between university management team, teachers, students, employers and other actors, aimed at generating production and consumption value for all stakeholders. We will further describe why and how social media is an efficient tool of promoting value co-creation and implementing it into a marketing management process.

\section{Methodological approach}

This research paper is based on the analysis of the secondary data, as well as some previous research papers on VCC in other market fields.

In order to study the role of social media in the VCC process, data from journals, books and other research papers are collected. The material is then used to formulate the benefits of social media platforms as the engagement platforms for the VCC process.

To analyze the current role of social media on the HE market in Ukraine in regard to VCC, we identify institutions and social media to be considered by referred to the current statistical data by Statcounter and Similar Web as well as the last edition of Webometrics rating.

According to Statcounter monitoring (2018), the Top-5 used social media platforms in Ukraine as of September 2018 are Facebook with $53.11 \%$ of users, Instagram with $16.79 \%$, Youtube with $9.1 \%$, Pinterest with $8.88 \%$, and Twitter with $5.8 \%$.

Webometrics is aimed at ranking all the higher educational and academic establishments in the world according to their presence on the Web. For the purpose of our paper, we are interested in top 5 Ukrainian Universities, listed in the rank, although their place in the global rank is rather low. Ukrainian web leader - National Taras Shevchenko University of Kyiv takes 1271 position in the global Webometrics rating.

Based on the Webometrics data, further research will take the following list of the universities into account:

1. National Taras Shevchenko University (NTSU), Kyiv - 25000 students;

2. National Technical University of Ukraine "Kyiv Polytechnic Institute" (KPI), Kyiv - 30000 students;

3. Ivan Franko National University (LNU), Lviv - 19600 students;

4. Sumy State University (SSU), Sumy - 15800 students;

5. Kharkiv National University VN Karazin (KhNU), Kharkiv - 16000 students.

To analyze their social media activity, we will use data from Facebook, Instagram and Youtube - the most popular social media platforms in Ukraine as mentioned above. The online tool Socialbakers was used to get aggregated information on Social media activities of the universities. The current number of students was retrieved from the website www.osvita.ua/vnz/guide. The following metrics will be given below for each university in question: 
for Facebook:

- number of fans;

- number of posts for 1 month (from October 9th to November 8th);

- average number of interactions per post for the period;

for Instagram:

- average number of comments per post for the period.

- number of followers;

- total number of posts;

- number of posts for 1 month (from October 9th to November 8th);

- average number of likes per post for the period;

for Youtube:

- average number of comments per post for the period.

- number of subscriptions;

- number of videos for 1 month (from October 9th to November 8th);

- average number of views per video;

- average number of reactions per video.

Interactions per 1000 fans and interactions per 1000 fans per post for the period will be calculated for all three social networks. The audience covering rate is calculated as the ratio of number of Facebook fans and the number of students for the current year.

\section{Conducting research and results}

\subsection{The role of SM in VCC for higher education}

The main challenge of value co-creation is organizing an appropriate environment, where different actors will meet, exchange their resources and generate value following the rules of a win-win strategy. All participants are supposed to benefit from the process. In addition, such environment should fit in a DART framework, introduced by Prahalad and Ramaswamy (2004a, 2004b). The latter includes four core elements of consumer-company interaction: dialogue, access, risk-benefits assessment, and transparency.

The role of such an environment is supposed to be played by engagement platforms. Briedbach et al. (2014) integrate the concept of engagement platforms in marketing and identify the crucial role of platforms in facilitating interactions, value co-creation, and engagement amongst actors of the service ecosystem. Based on prior research, Briedbach and Brodie (2017) determine engagement platforms as the main practitioners' tool. These platforms allow bridging the theoretical framework of S-D logic with managerial practice. In terms of HE, their main function is to connect economic actors of education service ecosystem, to provide organizational structures for cooperation and resource integration which will result in value cocreation.

In this paper we will focus on social media as an engagement platform for value cocreation. Social media is "a group of internet-based applications that build on the ideological and technological foundations of Web 2.0, and that allow the creation and exchange of User Generated Content" (Kaplan, Haenlein, 2010, p.61). Social media become the most convenient engagement platforms to be used by HE institutions in the process of value co-creation for several reasons, which we outline in Figurel as FEES characteristics.

Familiarity. These platforms are familiar to all users and there is no need to overcome resistance of actors. In 2017 2,46 billion people used social networks around the globe. This accounts to $71 \%$ of all internet users and the numbers are expected to increase in the next several years, reaching 3,02 billion people (eMarketer, 2018). Students, companies and university 
members mostly use these platforms for their professional and personal communication; therefore, they will only broaden their use cases.

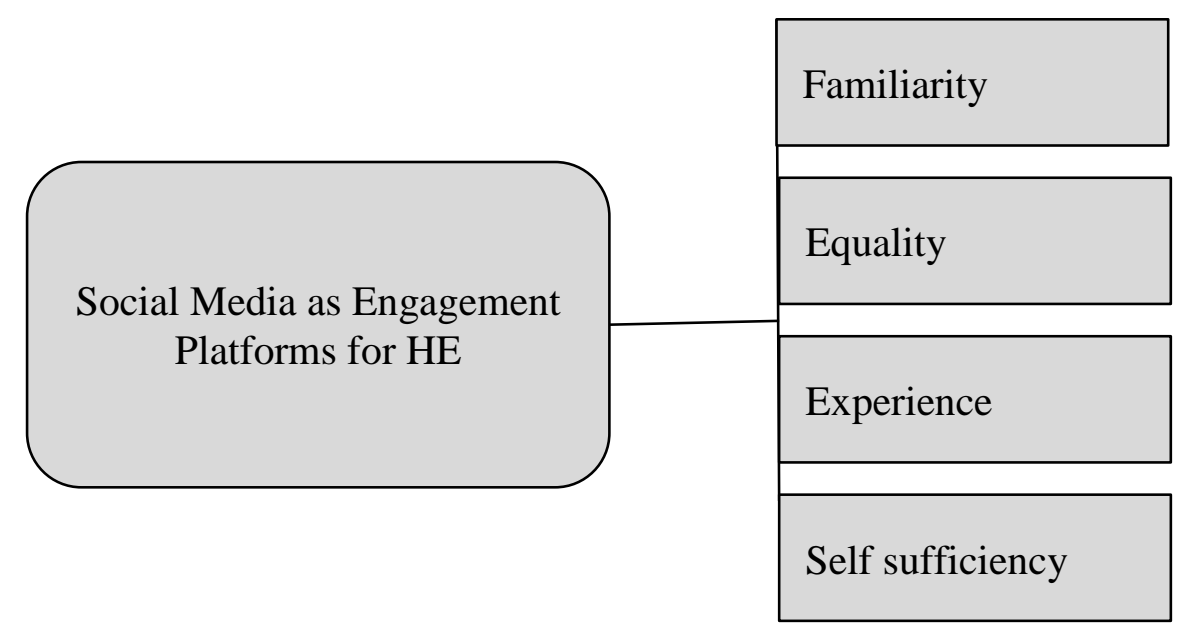

Figure 1. Social Media “FEES” Characteristics as Engagement Platforms for HE

Equality. Interaction on SM platforms is equal, barrier free and devoid of formal roles. These characteristics are best suited for encouraging all actors to share opinions, complaints, negotiate, endorse, and interact (Cova, Dalli, 2009).

Experience. Social and experiential knowledge is dominant in the process of communication through the Internet and SM (Sawhney et al., 2005). That allows us to extend co-creation practice from solely co-production to value-in-use. Social media are viewed by Charkabarti and Ramaswamy (2014) as co-consumption platforms, which provide experience, contrary to co-production platforms, where individuals contribute to the design of goods. But for higher education services it can be argued that social media may facilitate both coconsumption and co-production: knowledge, generated by all participants of the communication with the help modern SM tools (e.g., polls, questionnaires, video-interviews) is the main service, provided to the consumers.

Self-sufficiency. Social media platforms need few university resources to be operated. They are already self-sufficient instruments for value co-creation, where UGC accounts for most of the information generated. Nonetheless, Schiavone et al. (2014) emphasize that in case of using social media as the engagement platforms for value co-creation, much attention should be paid to technology management. Extending the DART model (Prahalad, Ramaswamy, 2004a, 2004b), to DARTT, they point out that technology management is seen as "the ability to aggregate customers and engage them, to carry out actions through social media that encourage them to make contributions and support their active participation" (Schiavone, Metallo, Agrifoglio, 2014, p.277).

\subsection{SM of Ukrainian Universities: analysis and findings}

Below social media activity metrics are described. Facebook activity metrics are given in Table 1. The audience covering rate for university Facebook pages is the highest for LNU 0,66 and the lowest for KPI - 0,1. Having the largest number of students amongst analyzed institutions (30000 students), KPI has a high potential of increasing their fans base on Facebook and making it more efficient. For the rest of the universities the number of fans is much lower than the number of students currently studying at the university. 
Table 1. Facebook metrics for Ukrainian universities, October-November, 2018

\begin{tabular}{lccccc}
\hline Metric/University & NTSU & KPI & LNU & SSU & KhNU \\
\hline Fans & 13808 & 2975 & 12839 & 1770 & 12056 \\
\hline Fans/Students & 0,55 & 0,10 & 0,66 & 0,11 & 0,75 \\
\hline Posts & 69 & 33 & 45 & 3 & 82 \\
\hline Average interactions per post & 51 & 30 & 24 & 11 & 26 \\
\hline Average comments per post & 0.7 & 3.7 & 0.3 & 0 & 0.2 \\
\hline Interactions per 1000 fans & 257.11 & 1.01 & 87.11 & 0 & 5.14 \\
\hline Interactions per 1000 fans per post & 3.73 & 0.03 & 1.94 & 0 & 0.06 \\
\hline Source: Own compllation
\end{tabular}

Source: own compilation

Facebook activity of the top-5 digitally active universities mostly includes news posts about future or past university events. SSU is the least active, having posted only three times during a month. The rest of the universities are quite active, making 1 to 3 posts per day.

Nonetheless, the level of interaction, demonstrated by Facebook users, remains rather low. Universities, on average, gather not more than 51 interactions per post. For value cocreation comments would be the most useful type of interaction, where users might explain their reaction, ask and answer questions, give additional information on the issue. But the level of such interactions is extremely low: 0 for SSU, 0.2 for KhNU, 0.3 for NTSU. The highest rate of 3.7 demonstrated by KPI Facebook page was reached due to the political scandal, surrounding the University at that time. Topics, that provoked the most active reaction of the audience were: politics, event videos, university students' and staff achievements, beauty contest. Some of the users' comments are interesting for value co-creation:

- political comments, demonstrating social position and cohesion of the audience;

- attitude to the beauty contest, showing current values of the audience and the need to correspond to them;

- direct advice to increase the quality of experience: "It's inconvenient to read from a mobile device, very small letters. Ask students to adapt it as a part of their practice classes".

Instagram activities are summarized in Table 2.

It is to be pointed out, that the number of followers on Instagram is much lower than that on Facebook for 4 out of 5 universities. KPI is the only institution with twice as more followers on Instagram than fans on Facebook. Therefore, all of them still have a base growth potential. The Instagram users in our case are more active than Facebook users. Each post is gathering more than 150 likes on average, with the KPI and KhNU gathering 669 and 727 likes per post respectively. The level of interactions per 1000 fans demonstrates high level of engagement of the audience, signaling universities, that it is ready to interact on this platform.

Contrary to users' activity, institutions' activity on Instagram is rather poor. NTSU and LNU post on Instagram 15 times less, than on Facebook, though their followers are ready to cooperate on the platform. The highest level of activity is demonstrated by KhNU and their fans are willing to respond, giving on average 727 likes and 5 comments to 1 post.

Higher level of followers' activity can be explained by the overall mood and the language of the posts on Instagram - they are more student oriented and informal, though covering the same topics as on Facebook, but in a smaller volume. At the same time Facebook posts are quite formal, but more often, trying to inform users about most of the events taking place on campus. 
Table 2. Instagram metrics for Ukrainian universities, October-November, 2018

\begin{tabular}{lccccc}
\hline Metric/University & NTSU & KPI & LNU & SSU & KhNU \\
\hline Followers & 1417 & 6656 & 2051 & 1246 & 7984 \\
\hline Followers/Students & 0,06 & 0,22 & 0,1 & 0,08 & 0,5 \\
\hline Posts, total & 110 & 328 & 41 & 81 & 836 \\
\hline Posts, 1 month & 5 & 5 & 3 & 10 & 26 \\
\hline Average likes per post & 152 & 669 & 443 & 165 & 727 \\
\hline Average comments per post & 0,6 & 1,8 & 0 & 1 & 5 \\
\hline Interactions per 1000 fans & 539 & 503 & 649 & 1334 & 2385 \\
\hline Interactions per 1000 fans per post & 100 & 100 & 216 & 133 & 92 \\
\hline Source:
\end{tabular}

Source: own compilation

YouTube turned out to be the social network with the least level of cooperation amongst actors (see Table 3). Only three universities (KPI, SSU, KhNU) are positioning their YouTube channel as an official one. LNU has a channel, managed by students and positioned as a student's TV, while NTSU is not presented on YouTube at all. High level of interaction for KPI YouTube channel was reached due to videos, covering political issues, university was dealing with at the time. The fullest coverage of the university life is done by KhNU YouTube channel administrators. But on account of the low number of subscribers (529) videos are not much viewed and have the lowest level of interaction amongst competitors.

Table 3. YouTube metrics for Ukrainian universities, October-November, 2018

\begin{tabular}{lccccc}
\hline Metric/University & NTSU & KPI & LNU & SSU & KhNU \\
\hline Subscribers & - & 5319 & 1450 & 177 & 529 \\
\hline Subscribers/Students & - & 0.18 & 0.07 & 0.01 & 0.03 \\
\hline Videos, 1 month & - & 19 & 5 & 3 & 15 \\
\hline Average views per video & - & 1057 & 155 & 41 & 8 \\
\hline Average reactions per video & - & 32 & 6 & 0.3 & 0.1 \\
\hline Interactions per 1000 fans & - & 3890 & 555 & 700 & 229 \\
\hline Interactions per 1000 fans per post & - & 204 & 111 & 233 & 29 \\
\hline Source:
\end{tabular}

Source: own compilation

\section{Conclusion and implications}

The objective of this paper was to describe how social media might be used in the process of value co-creation in order to increase competitiveness of Ukrainian HE institutions. Used to encourage A2A cooperation and resource integration, they are the best place to connect universities with their two main target audiences: students and employers. But it is to be mentioned that the analyzes of current SM usage in Ukraine showed that HE institutions, as well as students and employers, are rather passive in the process of value co-creation. Having their corporate pages on top three SM platforms in Ukraine - Facebook, YouTube, and Instagram - universities do not actively use them to stimulate resources' exchange and therefore experience low user involvement and value co-creation. Figure 2 shows the current roles of all three actors in VCC of HE through SM platforms. 


\section{Current role of actors in VCC}
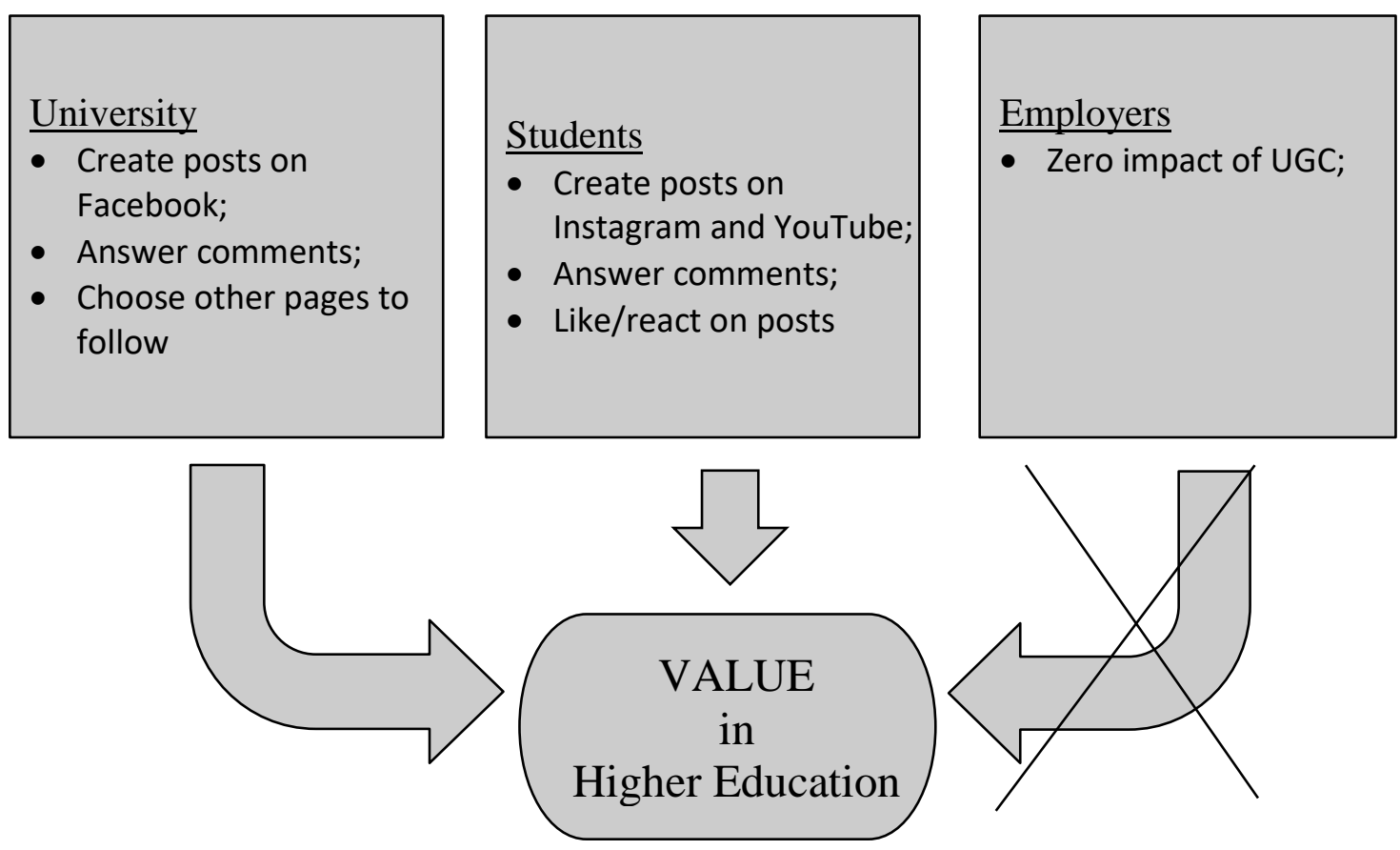

Figure 2. The roles of actors in VCC through SM

These roles, supported by numbers, analyzed in section three of the paper, demonstrate, that VCC in HE through social media can not become significant without university management function. The level of UGC, currently generated by university workers, students and future employers is extremely low and should be purposefully stimulated.

Though the discussion on the advantages and disadvantages of education commercialization is still open, there is no doubt, that modern marketing tools should be used in HE if not to earn profits, but at least to increase generated customer value. Further research in this field should cover the issue of university role in the value co-creation process, transforming it from primary initiator and a further passive observer to an active technical manager. In addition, the problems of motivation for university staff need to be analyzed in order to close the gap between strategic value co-creation goals and tactical daily learning process approaches. As a result, a practical guide, describing the algorithm of value co-creation on SM platforms should be developed to ensure institutional benefits from value co-creation in higher education.

\section{Recommendations}

To gain from VCC through social media platforms, universities should understand the exact value which is generated in this process. In Table 2 we outline value dimensions for HE market, that can be addressed in the process of VCC on SM platforms.

These value dimensions were identified by Shet et al. (1991) in the theory of consumption values (TCV) and include 5 dimensions of value that influence consumer behavior: functional, social, emotional, epistemic, conditional. The co-creation process with the help of social media can benefit for each type of the value, mentioned below and for both groups of the target audience - students and employers. 
Table 4. The TCV value dimensions for HE market

\begin{tabular}{lll}
\hline \multicolumn{1}{c}{ Value type } & \multicolumn{1}{c}{ Students } & \multicolumn{1}{c}{ Employer } \\
\hline Functional & $\begin{array}{l}\text { Knowledge } \\
\text { Experience } \\
\text { Career opportunities }\end{array}$ & Skilled and talented employees \\
\hline Social & $\begin{array}{l}\text { Belonging to successful social } \\
\text { groups }\end{array}$ & Corporate social responsibility \\
\hline Emotional & Soft skills & $\begin{array}{l}\text { Lower emotional tension between } \\
\text { current and future employees }\end{array}$ \\
\hline Epistemic & $\begin{array}{l}\text { Dealing with modern technologies } \\
\text { and up-to-date issues }\end{array}$ & $\begin{array}{l}\text { Working with new labor market } \\
\text { generations } \\
\text { Source of new theoretical frameworks }\end{array}$ \\
\hline Conditional & Availability & $\begin{array}{l}\text { "Customization" opportunities } \\
\text { Lifelong learning }\end{array}$ \\
\hline
\end{tabular}

Functional value is usually the core value proposition of the company. To add consumer resources to functional value, one needs to draw them to co-production. Perceived functional value is usually experienced by students as their way of developing transferable skills, obtaining knowledge, reaching career goals. Moreover, according to Blyznyuk T. (2017), intelligence and education was ranked first among the instrumental values significant for Ukrainian generation Y, both for senior school pupils and for students. At the same time, employers are expecting new talents on a labor market. Knowledge sharing is considered to be a core mechanism of cocreating value. Including consumer knowledge into production processes is seen by authors as an effective way of gaining competitive advantage (Prahalad, Ramaswamy, 2000; Gibbert et al., 2002). In tertiary education students are no longer exclusive "sellers" of knowledge. Though it can be argued that professors still remain the best carriers and communicators of disciplinary knowledge, Bovill et al. (2014) point out that students are experts at being students and can contribute meaningfully to the education process. Future employers, at the same time, share their technical competences and practical knowledge. On social media platforms knowledge of all three groups can be easily combined and transferred. These platforms may be used for precourse or pre-class activities to investigate what aspects of the topic students are more interested in. Some current issues may be discussed in a form of commenting alternative theories, where everyone can express opinion and give arguments. In some fields, where practice goes before theory, employers' opinions may give insights for future students' research. And a trusted and efficiently managed university social media platform is the best place for such cooperation. Employers, in turn, taking an active role in an educational process through social media get an opportunity of "try-before-you-buy" at almost zero transaction costs.

Social dimension of value for students is expressed by the opportunity to create stronger connections with each other, university staff and future employers. Jalonen H. (2017) discusses the role of social media in providing identity and increasing sense of community. Taking part in discussions on SM platforms students become active participants in value co-creation giving their opinion on different educational and social issues, peer-reviewing, helping each other in conducting research etc. Comprising professors, employers and students as their fans and readers, social media platforms allows students to build relationships with more successful and self-sufficient social groups. Commercial and other organizations, employing graduates, through social media become co-creators of social value not only for students, but also for each other. Being free from any geographical barriers and time limits, they can easily build socially significant partnership with universities and other actors of the market, finding out of the box solutions for current problems, demonstrating their proactivity in the life of the society. 
Epistemic value in education has been prior identified by researchers as the primary benefit of learning experience as part of the process of completing a degree ( $\mathrm{Ng}$, Forbes, 2009; Ledden et al., 2007). In Ledden and Anderson research (2015) students demonstrated their desire for knowledge of relevant subject matter while choosing a study program. Social media platforms become a convenient board for exchanging news and interests with each other and academic staff, allowing the latter to include up-to-date issues into their course syllabus. Professors get an opportunity to talk not only about the topics that bother them, but also those, students are interested in, increasing the epistemic value of HE. In addition, the use of social media in education process demonstrates to students that their Alma Mater is easily dealing with modern technology and is open to innovations in educational tools, as well as in students' creativity. Crucial point in this process is choosing the right social media platform for value cocreation. Platforms, that are most widely used by students, university staff and employers in their life and work beyond education, will be the most beneficial in a value co-creation process: there will be no need in changing basic consumer behavior, but there will still be an opportunity to use these tools in a new way. For example, Instagram Stories or streaming Facebook services might be used by employers and professors to show the backstage of educational or production processes. While students may use SM to conduct polls or conjoint-analysis.

When talking about epistemic dimension of value for employers, we would like to emphasize three aspects of value co-creation through SM. Firstly, employers, taking part in generating content, giving educational cases and passing polls can satisfy their curiosity about new generations of employees before employing them. They can get information about their real interests, priorities, approaches to problem solving before integrating new workers to their corporate culture. Secondly, employers are taking part in new ways of cooperation - online webinars, post comments, answering questions, gathered through social media - contrary to the classical for a corporate world meetings and Skype conference calls. Thirdly, all actors of the co-creation process receive an opportunity to use new theoretical frameworks in practice. Students and academic staff can create the basis for company's innovations.

National University "Kyiv-Mohyla Academy" lead the value co-creation process in partnership with the International Association of Marketing Initiatives and an active role of students. An epistemic value was generated for all the actors through evaluating educational business cases on Facebook. In such a way new and innovative decision are usually found thanks to the active participation of all stakeholders - professors, students and employers. In this particular example Facebook was chosen as a platform for value co-creation.

Emotional value is perceived as a bunch of positive emotions, aroused by a product or service. Students through social media get a feeling of self-esteem and self-confidence in completing practical tasks, shared with them by professors, co-students and employers. Social media platforms also create the ability to express emotions and thoughts, not keeping them to yourself and getting a proper feedback. There are no longer long lists of students-introverts without the ability to express opinion due to time limits of the on-campus classes and extremely talkative colleagues. An Australian research, conducted by Kassenboehmer, Leung, and Schurer (2018) proves that tertiary education has positive effect on two non-cognitive skills extraversion and agreeableness for students from disadvantaged backgrounds. Researchers emphasize that it becomes possible due to students' exposure to university life: participation in club activities, social functions, and a continuous communication with fellow students and academic staff (Kassenboehmer, Leung \& Schurer, 2018). Social media platforms are a good place for such communication. In addition, they change the role of students from passive recipients of the information to active and fully equal participators of the educational process.

In terms of emotional dimension of value, employers also benefit from value co-creation through social media. When incorporating new employees, they often face the problem of 
conflicts between newcomers and current workers. The former are perceived as low skilled and the latter are not willing to waste their time on mentoring. Introducing current employees to the mentoring process while newcomers are still students and do not create a direct threat lowers emotional tension between current and future employees.

Conditional value may differ much depending on a situation, but some examples can be mentioned here. Social media platforms make all actors of tertiary education available 24/7 and on broader number of questions. That is why posting a question on Instagram or Facebook can be seen as the best alternative for receiving an on-time answer. At the same time employers may include some up-to-date issues into educational discussions not waiting for the course syllabus to be changed in the next academic year. Salmi (2001, p.109), talking about changes in education needs specifies the "short shelf life of knowledge" and insists on the importance of continuing lifelong education. SM university platforms can become a context where this process may take place. In National University "Kyiv-Mohyla Academy" alumni always receive email invitations for open lectures and other educational events. But such communication may also be organized on SM platforms in a form of Live YouTube video with the opportunity to ask questions. Another way is to post an event and open registration via Facebook. Users and the university then will be able to see what audience is going to attend the event and ask the audience to put questions in advance, to cover deeply those issues during the event.

Following the inclusive capitalism concept, the participants of the Business Roundtable, held in August 2019 in the US, put other stakeholders and their values in line with investors (Markey, 2020) and "committed to lead their companies for the benefits of all stakeholders" (Scott, 2019). That said, value co-creation should generate additional benefits not only for customers (students and employers), providing them with excellent service and relevant knowledge and skills. The State and Direction of Inclusive Capitalism Report (2018) emphasizes business's "purposes" for three more groups: providing livelihoods and meaning to employees; delivering returns to providers of capital (either state or private); performing affirmative duties to society. And a suggested value co-creation process through SM platform has the potential to exert positive effect on these purposes. Namely, by creating a broader discussion of the current scientific and practical issues with the involvement of different stakeholders, this process may allow finding effective and efficient decisions of the local and global problems. Employees will consider themselves to be a part of a bigger community of like-minded researchers and practitioners. Government as the main investor will gain advantage of the more qualified workforce.

Given the wide range of value dimensions that can be co-created through SM, all actors are interested in the process. But universities' management should concentrate more on stimulating other users to participate. Covering mostly university events and other internal issues through SM, universities limit the number of people, interested in their page updates, willing to react and generate content. On the contrary, research results, up-to-date social and economic issues, and business cases could motivate employers, students and university staff to generate content and become more active in the process of value co-creation. University staff, currently demonstrating the lowest level of engagement on SM platforms, may need additional extrinsic motivation tools to be applied. Corporate online training programs, showcases, joint lectures with distant speakers, creation of a premium fund can be among the steps, taken by university management to encourage employees to use SM in their teaching process. Consequently, employee engagement in value co-creation through SM will lead to corporate culture shifts, essential for further digital transformation of the universities: frequent sharing of insights, successes, and failures; freedom to make small moves on the front line; becoming less afraid of failure (Bughin, Catlin, LaBerge, 2019). In turn, broadening the borders of educational 
process from campus to SM gives universities an opportunity to improve teaching methods. Interactive changes and new methods, corresponding with current global and local trends may become a source of competitive advantage and additional value in HE.

\section{References}

Blyznyuk, T. (2017). Generational Values of Generation Y: Survey of Ukrainian Senior School Pupils and Students. Economics and Sociology, 10(3), 153-166. doi:10.14254/2071789X.2017/10-3/11

Bovill, C., Felten, P., \& Cook-Sather, A. (2014). Engaging Students as Partners in Learning and Teaching: Practical Guidance for Academic Staff and Academic Developers. Conference: International Consortium in Educational Development, Stockholm.

Bowden, J., \& D'Alessandro, S. (2011). Co-creating Value in Higher Education: The Role of Interactive Classroom Response Technologies. Asian Social Science 7 (11), 35-49. doi: 10.2239/ass.v7n11p35

Breidbach, C. F., \& Brodie, R. J. (2017). Engagement Platforms in the Sharing Economy: Conceptual Foundations and Research Directions. Journal of Service Theory and Practice 27 (4), 761-777. doi: 10.1108/JSTP-04-2016-0071

Breidbach, C.F., Brodie, R.J., \& Hollebeek, L. (2014). Beyond Virtuality: From Engagement Platforms to Engagement Ecosystems. Managing Service Quality 24(6), 592-611. doi: 10.1108/MSQ-08-2013-0158

Bughin, J., Catlin, T., \& LaBerge, L. (2019) The Drumbeat of Digital: How Winning Teams Play. McKinsey Quartely 3, 1-11. Retrieved from: https://www.mckinsey.com/quarterly/the-magazine/2019-issue-3-mckinsey-quarterly

Charkabarti, A., \& Ramaswamy, V. (2014). Re-thinking the Concept of Surplus: Embracing Co-creation Experiences in Economics. Ross School of Business paper No. 1188. Retrieved from https://papers.ssrn.com/sol3/papers.cfm?abstract_id=2291475

Chemi, T., \& Krogh, L. (2017). Co-Creation in Higher Education. Students and Educators Preparing Creatively and Collaboratively to Challenge the Future (ed.). Creative Education Book Series. Vol. 6.

Cova, B., \& Dalli, D. (2009). Working Consumers: The Next Step in Marketing Theory? Marketing Theory 9(3), 315-339. doi: 10.1177/1470593109338144

Dollinger, M., Lodge, J., \& Coates, H. (2018). Co-creation in Higher Education: Towards a Conceptual Model. Journal of Marketing for Higher Education 28 (2), 210-231. doi:10.1080/08841241.2018.1466756

Gibbert, M., Leibold, M., \& Probst, G. (2002). Five Styles of Customer Knowledge Management, And How Smart Companies Put Them into Action. European Management Journal 20(5), 459-469. doi: 10.1016/S0263-2373(02)00101-9

Jalonen, H. (2017). Social Media as a 'Service' For Value Co-creation by Integrating Sponsoring Companies, Sports Entities and Fans. World Journal of Nuclear Science and Technology 11(1), 2381-2388.

Kaplan, A.M., \& Haenlein, M. (2010). Users of the World, Unite! The Challenges and Opportunities of Social Media. Business Horizons 53(1), 59-68. doi:10.1016/j.bushor.2009.09.003

Kassenboehmer, S. C., Leung, F., \& Schurer, S. (2018). University Education and Noncognitive Skill Development. Oxford Economic Papers 70(2), 538-562. doi:10.1093/oep/gpy002

Ledden, L., \& Anderson, J.E. (2015, July). Consumer Value Co-Creation in Higher Education. Paper presented at the Magic in Marketing Conference in Limerick Ireland. 
Ledden, L., Kalafatis, S.P., \& Samouel, P. (2007). The Relationship Between Personal Values and Perceived Value of Education. Journal of Business Research 60(9), 965-974. doi:10.1016/j.jbusres.2007.01.021

Maechler, N., Necher, K., \& Park, R. (March, 2016). From Touchpoints to Journeys: Seeing the World as Customers Do. McKinsey Quarterly. Retrieved from https://www.mckinsey.com/business-functions/marketing-and-sales/our-insights/fromtouchpoints-to-journeys-seeing-the-world-as-customers-do.

Markey, R. (2020) Are You Undervaluing Your Customer? Harvard Business Review 01. Retrieved from https://hbr.org/2020/01/the-loyalty-economy

Ng, I., \& Forbes, J. (2009). Education as Service: The Understanding of University Experience Through the Service Logic. Journal of Marketing for Higher Education 19(1), 38-64. doi:10.1080/08841240902904703

Prahalad, C. K., \& Ramaswamy, V. (2000). Co-opting Customer Competence. Harvard Business Review 78(1), 79-87. Retrieved from http://www.venkatramaswamy.com/articles_files/2000-hbr.html

Prahalad, C.K., \& Ramaswamy, V. (2004a) The Future of Competition: Creating Unique Value with Customers, Harvard Business School Press, Boston, MA.

Prahalad, C.K., \& Ramaswamy, V. (2004b). Co-creation Experiences: The Next Practice in Value Creation. Journal of Interactive Marketing 18(3), 5-14. doi: 10.1002/dir.20015

Salmi, J. (2001). Tertiary Education in the Twenty-First Century Challenges and Opportunities. Journal of the Programme on Institutional Management in Higher Education. Higher Education Management: Education and Skills 13(2), 105-130.

Sawhney, M., Verona, G., \& Prandelli, E. (2005). Collaborating to Create: The Internet as a Platform for Customer Engagement in Product Innovation. Journal of Interactive Marketing 19(4), 4-17. doi:

Schiavone, F., Metallo, C., \& Agrifoglio, R. (2014). Extending the DART Model for Social Media. International Journal of Technology Management. 66(4), 271 - 287. doi:10.1002/dir.20046

Scott, M. (2019, September 13) U.S. Business Embrace Inclusive Capitalism - But Do They Know What This Means? Retrieved from https://www.forbes.com/sites/mikescott/2019/09/13/us-businesses-embrace-inclusivecapitalismbut-do-they-know-what-this-means/\#26f573c83fbc

Sheth, J.N., Newman, B.E., \& Gross, B.L. (1991). Why We Buy What We Buy: A Theory of Consumption Values. Journal of Business Research 22(2), 159-170. doi: 10.1016/01482963(91)90050-8

The State And Direction of Inclusive Capitalism (2018), Saïd Business School, Ford Foundation \& Deloitte Social Impact Practice. Retrieved from https://www.sbs.ox.ac.uk/sites/default/files/201810/In\%20Pursuit\%20of\%20Inclusive\%20Capitalism\%20V2.pdf

Vargo, S. L., \& Lusch, R. F. (2004). Evolving to a New Dominant Logic in Marketing. Journal of Marketing 68 (Jan), 1-17. doi: 10.1509/jmkg.68.1.1.24036

Voropai, O. (2016). Value Co-creation Management: Aspects of Students' Involvement at Ukrainian Universities. Scientific Papers NaUKMA. Economics, 1(1), 30-34. doi:10.18523/2519-4739112016124779

www.socialbakers.com. Retrieved November 8, 2018 from http://www.socialbakers.com

www.statcounter.com. Retrieved November 8, 2018 from http://gs.statcounter.com/socialmedia-stats/all/ukraine/\#monthly-201809-201809-bar

www.webometrics.com. Retrieved November http://www.webometrics.info/en/Europe/Ukraine\%20

12, 2018 from 